\title{
How extraction method affects yield, fatty acids composition and bioactive properties of cardoon seed oil?
}

\author{
Spyridon A. Petropoulos ${ }^{\mathrm{a}, *}$, Ângela Fernandes ${ }^{\mathrm{b}}$, Ricardo C. Calhelha ${ }^{\mathrm{b}}$, Nikolaos Danalatos ${ }^{\mathrm{c}}$, \\ Lillian Barros ${ }^{\mathrm{b}}$, Isabel C.F.R. Ferreira ${ }^{\mathrm{b}, * *}$ \\ ${ }^{a}$ Laboratory of Vegetable Production, University of Thessaly, Fytokou Street, 38446 N. Ionia, Magnissia, Greece

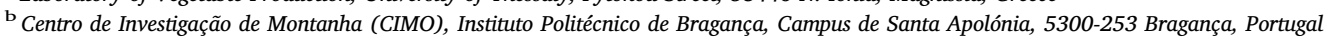 \\ ${ }^{c}$ Laboratory of Agronomy and Applied Crop Physiology, University of Thessaly, Fytokou Street, 38446 N. Ionia, Magnissia, Greece
}

\section{A R T I C L E I N F O}

\section{Keywords:}

Cynara cardunculus L.

Cardoon

Oil extraction

Mechanical pressing

Screw pressing

Hepatotoxicity

\begin{abstract}
A B S T R A C T
Cardoon (Cynara cardunculus L.; Asteraceae) is a perennial species with several uses, especially in the industry of energy production, while it is classified as a non-conventional energy crop within the European Union (EU). The aim of the present study was to evaluate chemical composition and antioxidant properties of cardoon seed oils extracted with two mechanical pressing methods, while at the same time it further determined composition and antioxidant properties of the obtained seedcakes. Oil extraction yield did not differ between the tested methods and growing years, indicating that both heat and cold extraction are efficient methods for oil production (approx. $75 \%$ extraction yield). Oils obtained from heat extraction method had better antioxidant properties than cold pressed oils, while significant variation between the growing years was also observed. Seedcakes of heat extraction method had the highest total phenols ( $405 \mathrm{mg}$ Gallic acid equivalents (GAE)/g extract) and the highest antioxidant properties for all the tested assays (with the exception of reducing power assay). Moreover, none of the studied materials (seeds, seed oils, and seedcakes) showed toxicity effects against PLP2 non-tumor cells $\left(\mathrm{GI}_{50}>400 \mu \mathrm{g} / \mathrm{mL}\right)$. The main fatty acids were linoleic and oleic acids which were detected in similar amounts in oils and seedcakes, while significant variation was observed between the tested methods and the growing years. The results of the present study signified the importance of cardoon as an alternative field crop under the Mediterranean climate conditions. In addition, seed oil production byproducts (e.g. seedcakes) are a promising material due to its bioactivities and its fat content and fatty acid composition, that could find alternative uses in the pharmaceutical and cosmetics industry.
\end{abstract}

\section{Introduction}

Cardoon (Cynara cardunculus L.; Asteraceae) is a perennial species native to the Mediterranean basin, which consists of globe artichoke ( $C$. cardunculus var. scolymus (L.) Fiori), as well as leafy cardoon; the latter is further divided into two cultivar groups, namely cultivated cardoon (C. cardunculus var. altilis DC) and wild cardoon (C. cardunculus var. sylvestris (Lamk) Fiori) (Pagnotta et al., 2017; Raccuia et al., 2011). Cultivated and wild cardoon have been traditionally used for its edible leaf stems (Renna et al., 2018), while in many regions of the Mediterranean plant immature inflorescences are also consumed in various gourmet dishes (Christaki et al., 2012; Fernández et al., 2006), or in the cheese-making industry (Almeida and Simões, 2018). However, during the last decades there is a great interest for industrial applications of cultivated cardoon, focusing on energy and biofuel production, with several studies confirming the great potential of the species for such purposes (Angelini et al., 2009; Grammelis et al., 2008; Vasilakoglou and Dhima, 2014). According to Ferreira-Dias et al. (2018), cardoon seed oil is rich in triacylglycerols, sterols (especially $\beta$-sitosterol and $\Delta^{7}$ stigmastenol), as well as in tocopherols ( $\alpha$ - and $\delta$-tocopherols), while they suggested that chemical fingertip of oils may be used for the identification of growing site. Moreover, Curt et al. (2002) carried out a multi-year and multi-location experiment in order to evaluate seed oil production, and reported a great variation in oil yields between experimental locations $(20.0-31.6 \%)$ and the tested populations (22.0-28.8\%), which highlights the pivotal importance of both genetic material selection and climate conditions for the achievement of higher oil yields. In the study of Foti et al. (1999), a significant variation

\footnotetext{
* Corresponding author at: University of Thessaly, School of Agricultural Sciences, Fytokou Street, 38446 N. Ionia, Magnissia, Greece.

** Corresponding author.

E-mail addresses: spetropoulos@uth.gr (S.A. Petropoulos), iferreira@ipb.pt (I.C.F.R. Ferreira).
} 
between two growing years was observed in seed oil content of a wild cardoon landrace, whereas for two cultivated cardoon genotypes the variation was less profound. Moreover, Maccarone et al. (1999) suggested that genotype may have a significant effect on fatty acids composition of seed oils, while they also reported a variation between two growing years.

However, apart from pre-harvest factors seed oil yield could be also affected by the extraction method, where according to recent studies pretreatment of seeds with microwaves prior to cold extraction has been reported to increase oil yield in purslane (Delfan-Hosseini et al., 2017) and rapeseed seeds (Yang et al., 2013). Although solvent extraction is the most efficient method for seed oil extraction, mechanical pressing of seeds is most commonly used in industrial scale oil production due to several drawbacks of solvents extraction technique, including high cost of consumables, environmental burden, laborious processing steps and high production costs (Azadmard-Damirchi et al., 2010). Depending on the solvent used in each extraction method, chemical composition of the obtained oils may differ significantly in terms of phenolic compounds, sterols and fatty acids content (Kozłowska et al., 2016), while differences in chemical composition of seed oils have been also observed between cold and heat-pressed oils attributed to temperature differences during seed processing and oil extraction (Delfan-Hosseini et al., 2017; Siger et al., 2017).

According to Petropoulos et al. (2017) and Petropoulos et al. (2018), apart from industrial use for energy production purposes, cardoon by-products could be used as bioactive compounds sources, thus increasing the added value of the crop. Oilcakes or seedcakes could also consist a valuable byproduct, since according to Bochkarev et al. (2016) seed oil and fat production byproducts of various plants such as pumpkin, flax, milk thistle, and soy present technological and nutritional properties that may find several alternative uses in the food industry. Moreover, Genovese et al. (2016) have highlighted the potential of using cardoon seedcakes as animal fodder which could further increase the overall added value of the crop.

Considering the great variation in cardoon grain yield reported in the literature (0.6-4.3 $\mathrm{tha}^{-1}$; (Curt et al., 2002; Foti et al., 1999; Gominho et al., 2011), the perennial nature of the species and oil extraction yield for mechanical pressing methods (up to $80 \%$ of total oil), the amount of byproducts in the oil production industry raises concerns regarding its management in an environmental friendly manner. Therefore, the aim of the present study was to evaluate oil yield of seeds from cardoon plants grown in the central Greece, with two extraction methods (heat and cold extraction) and in comparison with oil yield obtained with Soxhlet extraction. In addition, fatty acids composition of raw seeds, seed oils and seedcakes in relation to the extraction method and growing year was examined, while antioxidant activity and cytotoxicity were also determined in order to evaluate the potential of increasing the added value of the crop by using the seed oils and byproducts of oil production (seedcakes) as alternative raw materials for the pharmaceutical and cosmetics industry.

\section{Materials and methods}

\subsection{Plant material}

A field experiment was carried out at the experimental farm of the University of Thessaly in Velestino (22.756E, 39.396N), Greece during 2014-2015. Seeds of cultivated cardoon [Cynara cardunculus L. var. altilis DC] cv. Bianco Avorio (Fratelli Ingegnoli Spa, Milano, Italy) were collected from fully mature plants grown from seeds, starting four years after crop establishment (2014). Seeds were collected at the second fortnight of June for both the experimental years (2014-2015), as previously described by Petropoulos et al. (2018). Briefly, 50 cardoon plants with uniform growth were selected and one mature head from each plant (the central head of each compound of heads) was collected at principal growth stage 8 (code stage 89; Archontoulis et al. (2013)) and as soon as the heads were dry and senesced and the seeds fully ripened (Petropoulos et al., 2018). After the harvest, seeds were separated from the heads and batch samples were prepared for oil extraction with different methods, as described below (Section 2.2). Moisture content of seeds was recorded by putting ground whole seed samples in a forced-air oven at $72{ }^{\circ} \mathrm{C}$ until constant weight. Moreover, batch samples of whole seeds were ground with an electric ball mill (PX-MFC $90 \mathrm{D}$, Kinematica AG, Switzerland), freeze-dried and stored in deep freezing conditions $\left(-80^{\circ} \mathrm{C}\right)$ for antioxidant activity and cytotoxicity assays.

\subsection{Seed oil extraction methods}

For seed oil extraction, two different mechanical methods were implemented including one heat and one cold extraction method. Heat extraction was carried out with seeds collected at two consecutive years (2014-2015), whereas cold extraction was applied only for seeds collected at the last experimental period (2015). More specifically, heat extraction was carried out with the use of a small type screw oil press TäbyPressen Type 40 (Skeppsta Maskin AB, Örebro, Sweden). Oil temperatures during heat extraction ranged between $53-55^{\circ} \mathrm{C}$. Nozzle diameter was $6 \mathrm{~mm}$, while seeds were fed to the screw press at a seed feeding rate of $5 \mathrm{~kg} / \mathrm{h}$ and a rotational speed of $78 \mathrm{rpm}$. Cold extraction was carried out by Amygdalea S.A. (Volos, Greece) with the use of a Komet DD $85 \mathrm{G}$ twin screw vegetable oil expreller (IBG Monforts Oekotec GmbH \& Co.KG; Mönchengladbach, Germany). Oil temperatures during cold extraction 2 ranged between $40-44^{\circ} \mathrm{C}$. Nozzle diameter was $6 \mathrm{~mm}$, while seeds were fed to the screw presses at a seed feeding rate of $8 \mathrm{~kg} / \mathrm{h}$ and a rotational speed of $65 \mathrm{rpm}$. Oil extraction was carried out in triplicate for each tested method. For both methods, samples of oil were collected after $15 \mathrm{~min}$ of operation in order to allow the presses to achieve steady operation. After extraction, all seeds oils were centrifuged twice at $3500 \times g$ for $10 \mathrm{~min}$. After each centrifugation, the supernatants were collected in a new dark vial and stored at room temperature and dark conditions until further analysis.

Oil yield for each extraction method was estimated as the percentage of extracted oil ( $\mathrm{g}$ of oil) over the total amount of pressed seeds. For comparison purposes, total seed oil content was estimated with a Soxhlet apparatus. The samples $(10.0 \mathrm{~g})$ were extracted with $200 \mathrm{~mL}$ of petroleum ether by refluxing in a Soxhlet apparatus, during $8 \mathrm{~h}(\sim 32$ cycles, using a Soxhlet extractor with the capacity of $250 \mathrm{~mL}$ ) to assess oil recovery. Afterwards, the solvent was removed under reduced pressure (rotary evaporator Büchi R-210, Flawil, Switzerland), in order to obtain the oil content.

Seed cakes after oil extraction were also collected, freeze-dried (FeeeZone 4.5, Labconco, Kansas City, MO, USA), put in air sealed bags and stored at deep freezing conditions $\left(-80^{\circ} \mathrm{C}\right)$ until further analysis. Moisture content of seedcakes was also recorded by putting ground seed samples in a forced-air oven at $72{ }^{\circ} \mathrm{C}$ until constant weight

\subsection{Fatty acids composition analyses}

Fatty acids of seeds, seed cakes and seed oils were analyzed with a DANI 1000 gas chromatographer (GC) coupled to a flame ionization detector (FID) after a transesterification procedure described by Heleno et al. (2009) and results were recorded and processed using Clarity 4.0.1.7 Software (DataApex, Podohradska, Czech Republic).

\subsection{Antioxidant activity assays}

Extracts from freeze-dried samples of seeds and seed cakes were prepared by stirring the dry sample $(1 \mathrm{~g})$ and $30 \mathrm{~mL}$ of methanol/water $\left(80: 20 \mathrm{v} / \mathrm{v}\right.$, at $25^{\circ} \mathrm{C}$ at $\left.150 \mathrm{rpm}\right)$ for $1 \mathrm{~h}$ and afterwards filtered using Whatman paper No. 4 . The residue was then extracted with an additional portion of $(30 \mathrm{~mL})$ methanol/water and the combined extracts were evaporated under reduced pressure, until complete removal of 
methanol. The aqueous phase was frozen and lyophilized.

The seed oils $(5 \mathrm{~mL})$ were extracted by liquid-liquid with $10 \mathrm{~mL}$ of methanol, this procedure was repeated 3 time. Then the combined extracts were evaporated under reduced pressure until dryness.

The extracts from seeds and seed cakes, and seed oils were re-dissolved in methanol/water $(80: 20 \mathrm{v} / \mathrm{v})$ and methanol, to a final concentration of $10 \mathrm{mg} / \mathrm{mL}$ and $100 \mathrm{mg} / \mathrm{mL}$, respectively. Then they were further diluted to different concentrations, to be submitted to distinct in vitro antioxidant activity assays. For the purposes of the study four in vitro assays were performed as previously described by Sarmento et al. (2015). In particular, the 2,2-diphenyl-1-picrylhydrazyl (DPPH) radical-scavenging activity, reducing power assay, inhibition of $\beta$-carotene bleaching, and lipid peroxidation inhibition using porcine brain homogenates (TBARS assay). Trolox was used as a positive control.

\subsection{Determination of total phenols content (TPC)}

The total phenolic content of seeds, seed cakes and seed oils extracts (mentioned above in 2.4) were determined with the Folin- Ciocalteu method based on the procedures previously described by Wolfe et al. (2003), with some modification performed by the authors (Sarmento et al., 2015). The absorbance was measured at $765 \mathrm{~nm}$ (AnalytikJena 200 spectrophotometer, Jena, Germany) and gallic acid (0.8-0.05 mM) was used as a reference compound to obtain the calibration curve (y $\left.=1.8072-0.0211 ; R^{2}=0.999\right)$. The results were expressed as $\mathrm{mg}$ of gallic acid equivalents (GAEs) per gram of extract.

\subsection{Hepatotoxicity assays}

The extracts were re-dissolved at a concentration of $8 \mathrm{mg} / \mathrm{mL}$ in water and DMSO (10\%), and then they were further diluted to different concentrations ( 400 to $6.25 \mu \mathrm{g} / \mathrm{mL}$ ). The hepatotoxicity was evaluated against non-tumor porcine liver cell line (PLP2), obtained using a cell culture from freshly harvested porcine liver acquired from certified slaughterhouses. To monitor the cell culture growth a phase-contrast microscope was used, and then the cells were sub-cultured and plated in 96 well plates (density of $1.0 \times 10^{4}$ cells/well), uaing a DMEM medium, with $10 \%$ of FBS, $100 \mathrm{U} / \mathrm{mL}$ of penicillin and $100 \mu \mathrm{g} / \mathrm{mL}$ of streptomycin. The results were obtained using the Sulphorhodamine assay, as previously performed by Sobral et al. (2016). Results were expressed as $\mathrm{GI}_{50}(\mu \mathrm{g} / \mathrm{mL})$ and Ellipticine was used as a positive control.

\subsection{Statistical analysis}

For chemical composition analyses, antioxidant activity and cytotoxicity assays, three samples were analyzed for each treatment, whereas all the assays were carried out in triplicate. The results were expressed as mean values and standard deviations (SD), and analyzed using one-way analysis of variance (ANOVA) followed by Tukey's HSD Test with $p=0.05$. This analysis was carried out using SPSS v. 23.0 program (IBM Corp., Armonk, NY, USA).

\section{Results and discussion}

\subsection{Oil yield}

Seed oil yield, seedcakes fat content and oil extraction yield are presented in Table 1. Fat content of seeds obtained with Soxhlet extraction ranged between 23.5 and $24.02 \mathrm{~g} / 100 \mathrm{~g}$ dw from seeds collected during the growing period of 2015 and 2014, respectively. The application of mechanical pressing resulted in similar oil yields, regardless of the extraction method (heat or cold extraction), although a slightly lower yield was observed for cold extraction (75.5\% comparing to $77.8 \%$ and $78.3 \%$ ). Moreover, seedcakes for both years and extraction methods contained oils in a range between 5.1 and $5.8 \mathrm{~g}$ of fat per $100 \mathrm{~g} \mathrm{dw}$, suggesting that approximately $25 \%$ of total fat of seeds remain in the seedcake after oil extraction. According to AzadmardDamirchi et al. (2010), oil yield was lower for cold pressing in comparison with solvent extraction for rapeseed seeds, although the authors of this study pretreated seeds with microwaves prior to mechanical pressing. Moreover, Willems et al. (2008) reported that mechanical pressing has limited extraction yield (up to $80 \%$, depending on the species), while other more sophisticated methods (gas assisted mechanical pressing) may allow higher yields (Venter et al., 2006). Screw pressing is an efficient method for oil extraction from seeds, while according to Willems et al. (2008) increasing temperature and pressure during extraction procedure increases oil yield. The fact that no great differences were observed between the two tested methods in our study could be attributed to the fact that no great differences in temperatures were detected during oil extraction $\left(53-55^{\circ} \mathrm{C}\right.$ and $40-44^{\circ} \mathrm{C}$ for heat and cold extraction, respectively). Therefore, more research is needed regarding the comparison between extraction methods with greater temperature differences, in order to evaluate the effect of extraction parameters on oil yield.

According to the literature, cardoon seeds are a rich source of oils with oil yields that depend on growing conditions and genotype (Curt et al., 2002). Therefore, the perennial nature of the species as well as its low requirements for chemical inputs due to acclimatization make it a profitable crop for biofuel and energy production (Gominho et al., 2011; Zanetti et al., 2013). The results of our study are in accordance with those previously reported in terms of seed oil yield and further signify the importance of the crop as an alternative field crop in a climate change environment.

\subsection{Fatty acids composition}

The main fatty acids of seed oils, and seeds and seedcakes are presented in Tables 2 and 3, respectively. Fatty acids profile of seed oils differed from that of raw seeds and seedcakes, with eighteen individual fatty acids being detected in seed oils and sixteen compounds in raw seeds and seedcakes (data not shown). However, the main detected fatty acids were similar in all the studied materials with slight differences among them (except for the raw seeds of 2014 which differed from the other tested materials in fatty acids profile and individual fatty acids composition). In particular, the main fatty acids detected in seed oils regardless of the growing year and extraction method were two unsaturated fatty acids, namely linoleic $(63.2 \%-65.0 \%)$ and oleic acid $(21.1 \%-22.6 \%)$, followed by saturated fatty acids (SFA), such as palmitic $(9.3 \%-9.5 \%)$ and stearic acid $(2.78 \%-2.94 \%)$. Similar fatty acids composition in oils has been also reported by Curt et al. (2002) who studied the effect of growing year, location and genetic material on fatty acid composition of seed oils. In the same study, it was suggested that variation in fatty acids composition between the tested locations (inter-location variation) was higher than that between the various populations (inter-population variation), without however significant differences being observed for the main fatty acids, meaning that oil composition of cardoon seeds is fairly stable (Curt et al., 2002).

In our study, polyunsaturated fatty acids (PUFAs) were the most abundant fatty acids in all the studied samples due to high content of linoleic acid, which also resulted in high ratios of PUFA/ SFA and n6/n3 fatty acids. Although, values of PUFA/SFA higher than 0.45 are considered beneficial for human health, the very high values of $n 6 / n 3$ fatty acids are not considered a health promoting feature according to the studies of Guil et al. (1996), Simopoulos (1999) and Liu et al. (2016), due to the high content of linoleic acid.

The high content of seed oils in linoleic acid along with the high seed oil content could be valorized for industrial production of linoleic acid, thus increasing the added value of the crop and reducing environmental burden due to better byproducts management, especially in the case of seed oil byproducts such as seedcakes. 
Table 1

Fat and oil content and extraction yield of the studied cardoon seed cakes and raw seed samples (means \pm SD).

\begin{tabular}{|c|c|c|c|c|c|}
\hline & \multicolumn{2}{|r|}{2014} & \multicolumn{3}{|c|}{2015} \\
\hline & Cardoon raw seeds & Cardoon seed cake heat extraction & Cardoon raw seeds & Cardoon seed cake heat extraction & $\begin{array}{l}\text { Cardoon seed cake } \\
\text { cold extraction }\end{array}$ \\
\hline Moisture content $(\mathrm{g} / 100 \mathrm{~g} \mathrm{dw})$ & $5.98 \pm 0.08 \mathrm{a}$ & $4.38 \pm 0.03 d$ & $5.38 \pm 0.03 b$ & $4.17 \pm 0.01 \mathrm{~d}$ & $4.99 \pm 0.02 c$ \\
\hline Fat $(\mathrm{g} / 100 \mathrm{~g} \mathrm{dw})^{\Psi}$ & $\begin{array}{l}24.02 \pm 0.04 a \\
\text { Cardoon raw seeds }\end{array}$ & $\begin{array}{l}5.32 \pm 0.04 c \\
\text { Heat extraction } \\
2014\end{array}$ & $\begin{array}{l}23.5 \pm 0.6 a \\
\text { Cardoon raw seeds }\end{array}$ & $\begin{array}{l}5.8 \pm 0.2 b \\
\text { Heat extraction } \\
2015\end{array}$ & $\begin{array}{l}5.1 \pm 0.2 b \\
\text { Cold extraction } 2015\end{array}$ \\
\hline Oil content $(\mathrm{g} / 100 \mathrm{~g} \mathrm{dw})^{¥ ¥}$ & $24.02 \pm 0.04 a$ & $18.7 \pm 0.6 \mathrm{~b}$ & $23.5 \pm 0.6 \mathrm{a}$ & $18.4 \pm 0.7 \mathrm{~b}$ & $17.74 \pm 0.3 c$ \\
\hline Extraction yield $(\%)^{Y Y Y}$ & $100 \mathrm{a}$ & $77.8 \pm 0.3 b$ & $100 \mathrm{a}$ & $78.3 \pm 0.4 b$ & $75.5 \pm 0.8 c$ \\
\hline
\end{tabular}

Means in the same row followed by different Latin letters are significantly different according to Tukey test ( $p=0.05$ ).

$¥$ Fat content was determined with Soxhlet extraction for raw seeds and seed cakes.

$¥ ¥$ Seed oil content was determined with screw pressing for heat and cold extraction, while for cardoon seeds we assumed that it was the same as the content determined with Soxhlet extraction.

$¥ ¥ ¥$ Extraction yield was estimated as the percentage of oil extracted with screw pressing methods in comparison to fat content of raw seeds which is considered as $100 \%$.

Table 2

Composition of the main fatty acids of the studied cardoon seed oils samples (\%; mean $\pm \mathrm{SD})$.

\begin{tabular}{llll} 
& 2014 & \multicolumn{2}{c}{2015} \\
\cline { 3 - 4 } Fatty acids $^{¥}$ & Heat extraction & Heat extraction & Cold extraction \\
\hline C16:0 & $9.37 \pm 0.07 \mathrm{ab}$ & $9.3 \pm 0.2 \mathrm{~b}$ & $9.54 \pm 0.09 \mathrm{a}$ \\
C18:0 & $2.78 \pm 0.01 \mathrm{~b}$ & $2.8 \pm 0.1 \mathrm{~b}$ & $2.94 \pm 0.01 \mathrm{a}$ \\
C18:1n9 & $21.11 \pm 0.03 \mathrm{~b}$ & $21.1 \pm 0.3 \mathrm{~b}$ & $22.6 \pm 0.1 \mathrm{a}$ \\
C18:2n6 & $64.9 \pm 0.1 \mathrm{a}$ & $65.0 \pm 0.7 \mathrm{a}$ & $63.2 \pm 0.4 \mathrm{~b}$ \\
Total SFA (\% of total FA) & $13.23 \pm 0.07 \mathrm{ab}$ & $13.1 \pm 0.4 \mathrm{~b}$ & $13.5 \pm 0.2 \mathrm{a}$ \\
Total MUFA (\% of total & $21.34 \pm 0.02 \mathrm{~b}$ & $21.3 \pm 0.3 \mathrm{~b}$ & $22.9 \pm 0.1 \mathrm{a}$ \\
$\quad$ FA) & & & \\
Total PUFA (\% of total FA) & $65.43 \pm 0.08 \mathrm{a}$ & $65.6 \pm 0.7 \mathrm{a}$ & $63.6 \pm 0.3 \mathrm{~b}$ \\
PUFA/SFA & $4.95 \pm 0.03 \mathrm{a}$ & $5.0 \pm 0.2 \mathrm{a}$ & $4.7 \pm 0.1 \mathrm{~b}$ \\
n6/n3 & $114 \pm 6 \mathrm{~b}$ & $104 \pm 5 \mathrm{c}$ & $153 \pm 7 \mathrm{a}$ \\
\hline
\end{tabular}

Means in the same row followed by different Latin letters are significantly different according to Tukey test ( $p=0.05$ ).

C6:0 caproic acid, C14:0 myristic acid, C15:0 pentadecanoic acid, C16:0 palmitic acid, C16:1 palmitoleic acid, C17:0 heptadecanoic acid, C18:0 stearic acid, C18:1n9c oleic acid, C18:2n6c linoleic acid, C18:3n $\alpha$-linolenic acid, C20:0 arachidic acid, C20:1 eicosenoic acid, C20:3n3 + C21:0 cis-11,14,17-eicosatrienoic acid and heneicosanoic acid, C20:5n 3 eicosapentaenoic acid, C22:0 behenic acid, C22:1n9 erucic acid, C23:0 tricosanoic acid, C24:0 lignoceric acid, SFA: saturated fatty acids; MUFA: monounsaturated fatty acids; PUFA: polyunsaturated fatty acids; n6/n3: ratio of omega 6/omega 3 fatty acids.

$¥$ Only the fatty acids detected in percentages higher than $1 \%$ are presented.

\subsection{Antioxidant activities}

Antioxidant activities of seed oils, and seeds and seedcakes are presented in Tables 4 and 5, respectively. Significant differences were observed between the studied oils, not only between the different extraction methods, but also between the growing years (Table 4). Cold extracted oils exhibited better antioxidant activity of heat extracted oils in terms of DPPH and $\beta$-carotene/linoleate assays, whereas heat extracted oils had better antioxidant properties for reducing power and TBARS assays. Moreover, oils obtained with heat extraction from seeds collected in 2015 had the higher total phenolic content $(5.7 \mathrm{mg} \mathrm{GAE} / \mathrm{g}$ extract), followed by cold extraction of seeds from the same year (4.4 mg GAE/g extract), and heat extracted oils from seeds of 2014 (3.7 mg GAE/g extract).

In the case of seedcakes and raw seeds, total phenols were higher for seedcakes obtained from heat extraction of 2015 seeds, while raw seed had the lowest total phenols (Table 5). Moreover, except for reducing power assay, seedcakes obtained from heat extraction of 2015 presented the highest antioxidant properties, suggesting that great amounts of phenolic compounds remain in seedcakes and are responsible for its bioactivity. The differences in total phenols and antioxidant properties between seedcakes of the same oil extraction method, as well as between seedcakes of the same growing year, but from different oil extraction methods, indicate that growing year and extraction methods may affect bioactive compounds content of seed oil byproducts. Durazzo et al. (2013) have reported that antioxidant

Table 3

Composition in fatty acids of the studied cardoon seed cakes and raw seed samples (\%; mean \pm SD).

\begin{tabular}{|c|c|c|c|c|c|}
\hline \multirow[b]{2}{*}{ Fatty $\operatorname{acids}^{¥}$} & \multicolumn{2}{|c|}{2014} & \multicolumn{3}{|c|}{2015} \\
\hline & Cardoon raw seeds & $\begin{array}{l}\text { Cardoon seed cake } \\
\text { heat extraction }\end{array}$ & Cardoon raw seeds & Cardoon seed cake heat extraction & $\begin{array}{l}\text { Cardoon seed cake } \\
\text { cold extraction }\end{array}$ \\
\hline $\mathrm{C} 16: 0$ & $11.90 \pm 0.05$ & $9.97 \pm 0.03 b$ & $10.1 \pm 0.2 b$ & $9.5 \pm 0.1 d$ & $10.4 \pm 0.3 \mathrm{a}$ \\
\hline C18:0 & $3.18 \pm 0.01$ & $2.82 \pm 0.03 a$ & $2.75 \pm 0.01 b$ & $2.59 \pm 0.08 c$ & $2.76 \pm 0.04 \mathrm{ab}$ \\
\hline C18:1n9 & $12.81 \pm 0.01$ & $21.46 \pm 0.05 c$ & $23.48 \pm 0.03 a$ & $21.12 \pm 0.07 \mathrm{~d}$ & $23.2 \pm 0.1 b$ \\
\hline C18:2n6 & $70.41 \pm 0.06$ & $63.61 \pm 0.04 b$ & $61.83 \pm 0.07 c$ & $64.97 \pm 0.06 \mathrm{a}$ & $61.7 \pm 0.5 c$ \\
\hline SFA (\% of total FA) & $16.28 \pm 0.06 \mathrm{a}$ & $13.76 \pm 0.05 c$ & $13.7 \pm 0.1 \mathrm{c}$ & $13.14 \pm 0.05 \mathrm{~d}$ & $14.3 \pm 0.4 b$ \\
\hline MUFA (\% of total FA) & $13.08 \pm 0.01 \mathrm{e}$ & $21.75 \pm 0.05 c$ & $23.77 \pm 0.02 \mathrm{a}$ & $21.42 \pm 0.08 \mathrm{~d}$ & $23.5 \pm 0.1 b$ \\
\hline PUFA (\% of total FA) & $70.64 \pm 0.05 a$ & $64.49 \pm 0.01 c$ & $62.5 \pm 0.1 \mathrm{~d}$ & $65.44 \pm 0.03 b$ & $62.2 \pm 0.5 d$ \\
\hline PUFA/SFA & $4.34 \pm 0.05 d$ & $4.70 \pm 0.02 b$ & $4.55 \pm 0.05 c$ & $4.98 \pm 0.01 \mathrm{a}$ & $4.3 \pm 0.1 \mathrm{~d}$ \\
\hline $\mathrm{n} 6 / \mathrm{n} 3$ & $108.8 \pm 7 b$ & $72 \pm 4 c$ & $93 \pm 6 b$ & $139 \pm 9 a$ & $120 \pm 3 a$ \\
\hline
\end{tabular}

Means in the same column followed by different Latin letters are significantly different according to Tukey test $(p=0.05)$.

C6:0 caproic acid, C14:0 myristic acid, C15:0 pentadecanoic acid, C16:0 palmitic acid, C16:1 palmitoleic acid, C17:0 heptadecanoic acid, C18:0 stearic acid, C18:1n9c oleic acid, C18:2n6c linoleic acid, C18:3n 3 -linolenic acid, C20:0 arachidic acid, C20:1 eicosenoic acid, C20:3n3 + C21:0 cis-11,14,17-eicosatrienoic acid and heneicosanoic acid, C20:5n3 eicosapentaenoic acid, C22:0 behenic acid, C22:1n9 erucic acid, C23:0 tricosanoic acid, C24:0 lignoceric acid, SFA: saturated fatty acids; MUFA: monounsaturated fatty acids; PUFA: polyunsaturated fatty acids; n6/n3: ratio of omega 6/omega 3 fatty acids.

$¥$ Only the fatty acids detected in percentages higher than $1 \%$ are presented. 
Table 4

Total phenols, antioxidant properties and hepatotoxicity of the studied cardoon seeds oil samples (mean \pm SD).

\begin{tabular}{|c|c|c|c|c|}
\hline \multirow[b]{2}{*}{ Antioxidant activity assays ${ }^{X}$} & & \multirow{2}{*}{$\begin{array}{l}2014 \\
\text { Heat extraction }\end{array}$} & \multicolumn{2}{|c|}{2015} \\
\hline & & & Heat extraction & Cold extraction \\
\hline \multirow[t]{2}{*}{ Reducing power } & $\begin{array}{l}\text { Folin-ciocalteu } \\
\text { (mg GAE/g extract) }\end{array}$ & $3.7 \pm 0.9 c$ & $5.7 \pm 0.4 a$ & $4.4 \pm 0.1 b$ \\
\hline & $\begin{array}{l}\text { Ferricyanide/Prussian blue } \\
\left(\mathrm{EC}_{50} ; \mathrm{mg} / \mathrm{mL}\right)\end{array}$ & $10 \pm 1 b$ & $11 \pm 1 b$ & $14 \pm 2 a$ \\
\hline \multirow[t]{2}{*}{ Radical scavenging activity } & $\begin{array}{l}\text { DPPH scavenging activity } \\
\left(\mathrm{EC}_{50} ; \mathrm{mg} / \mathrm{mL}\right)\end{array}$ & $89 \pm 6 b$ & $96 \pm 9 a$ & $71 \pm 3 c$ \\
\hline & $\begin{array}{l}\beta \text {-carotene/linoleate } \\
\left(\mathrm{EC}_{50} ; \mathrm{mg} / \mathrm{mL}\right)\end{array}$ & $22 \pm 2 \mathrm{a}$ & $21 \pm 2 \mathrm{a}$ & $16 \pm 1 b$ \\
\hline Lipid peroxidation inhibition & $\begin{array}{l}\text { TBARS } \\
\left(\mathrm{EC}_{50} ; \mathrm{mg} / \mathrm{mL}\right)\end{array}$ & $7 \pm 1 b$ & $6.0 \pm 0.8 c$ & $9 \pm 1 a$ \\
\hline Hepatotoxicity & $\begin{array}{l}\text { PLP2 (non-tumor cells) } \\
\left(\mathrm{GI}_{50} ; \mu \mathrm{g} / \mathrm{mL}\right)\end{array}$ & $>400$ & $>400$ & $>400$ \\
\hline
\end{tabular}

Mean in the same column followed by different Latin letters are significantly different according to Tukey test ( $p=0.05$ ).

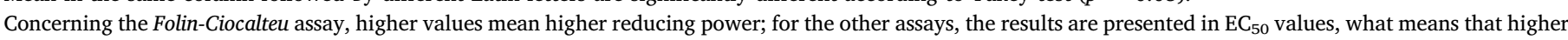

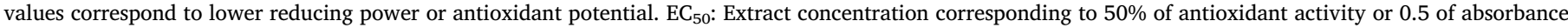

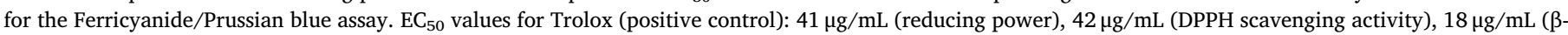
carotene bleaching inhibition) and $23 \mu \mathrm{g} / \mathrm{mL}$ (TBARS inhibition). $\mathrm{GI}_{50}$ values for Ellipticine (positive control): $3.2 \pm 0.7 \mu \mathrm{g} / \mathrm{mL}$.

$¥$ GAE: Gallic acid equivalents; EC $_{50}$ : Half maximal effective concentration; DPPH: 2,2-diphenyl-1-picrylhydrazyl; TBARS: Thiobarbituric acid reactive substances; PLP2: non-tumor porcine liver cell line; $\mathrm{GI}_{50}$ : corresponds to the sample concentration achieving $50 \%$ in liver primary culture PLP2.

Table 5

Total phenols, antioxidant properties and hepatotoxicity of the studied cardoon seed cakes and raw seeds samples (mean \pm SD).

\begin{tabular}{|c|c|c|c|c|c|c|}
\hline \multirow{2}{*}{\multicolumn{2}{|c|}{ Antioxidant activity assays ${ }^{\Psi}$}} & \multicolumn{2}{|r|}{2014} & \multicolumn{3}{|c|}{2015} \\
\hline & & Cardoon raw seeds & $\begin{array}{l}\text { Cardoon seed cake heat } \\
\text { extraction }\end{array}$ & Cardoon raw seeds & $\begin{array}{l}\text { Cardoon seed cake heat } \\
\text { extraction }\end{array}$ & $\begin{array}{l}\text { Cardoon seed cake cold } \\
\text { extraction }\end{array}$ \\
\hline \multirow[t]{2}{*}{ Reducing power } & $\begin{array}{l}\text { Folin-ciocalteu } \\
\text { (mg GAE/g extract) }\end{array}$ & $294 \pm 8 e$ & $332 \pm 4 c$ & $306 \pm 3 d$ & $405 \pm 3 a$ & $346 \pm 4 b$ \\
\hline & $\begin{array}{l}\text { Ferricyanide/ } \\
\text { Prussian blue } \\
\left(\mathrm{EC}_{50} ; \mathrm{mg} / \mathrm{mL}\right)\end{array}$ & $0.87 \pm 0.01 d$ & $0.106 \pm 0.003 b$ & $0.137 \pm 0.002 \mathrm{a}$ & $0.082 \pm 0.008 \mathrm{~d}$ & $0.094 \pm 0.003 c$ \\
\hline \multirow[t]{2}{*}{$\begin{array}{l}\text { Radical scavenging } \\
\text { activity }\end{array}$} & $\begin{array}{l}\text { DPPH scavenging } \\
\text { activity } \\
\left(\mathrm{EC}_{50} ; \mathrm{mg} / \mathrm{mL}\right)\end{array}$ & $1.14 \pm 0.01 \mathrm{a}$ & $1.08 \pm 0.02 b$ & $1.17 \pm 0.04 \mathrm{a}$ & $1.02 \pm 0.01 \mathrm{c}$ & $1.07 \pm 0.02 b$ \\
\hline & $\begin{array}{l}\beta \text {-carotene/linoleate } \\
\left(\mathrm{EC}_{50} ; \mathrm{mg} / \mathrm{mL}\right)\end{array}$ & $0.055 \pm 0.003 b$ & $0.045 \pm 0.002 c$ & $0.062 \pm 0.009 a$ & $0.038 \pm 0.007 d$ & $0.054 \pm 0.001 b$ \\
\hline $\begin{array}{l}\text { Lipid peroxidation } \\
\text { inhibition }\end{array}$ & $\begin{array}{l}\text { TBARS } \\
\left(\mathrm{EC}_{50} ; \mathrm{mg} / \mathrm{mL}\right)\end{array}$ & $0.125 \pm 0.002 \mathrm{a}$ & $0.029 \pm 0.001 \mathrm{~d}$ & $0.036 \pm 0.001 b$ & $0.024 \pm 0.001 \mathrm{e}$ & $0.032 \pm 0.001 c$ \\
\hline Hepatotoxicity & $\begin{array}{l}\text { PLP2 (non-tumor } \\
\text { cells) } \\
\left(\mathrm{GI}_{50} ; \mu \mathrm{g} / \mathrm{mL}\right)\end{array}$ & $202 \pm 17$ & $>400$ & $>400$ & $>400$ & $>400$ \\
\hline
\end{tabular}

Means in the same row followed by different Latin letters are significantly different according to Tukey test ( $p=0.05)$.

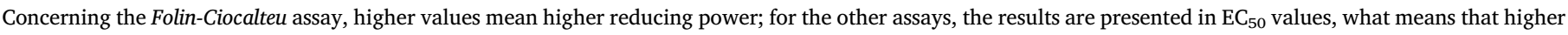

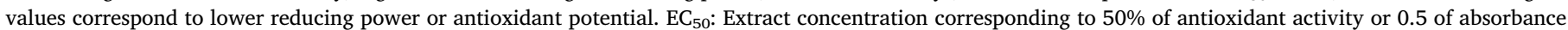

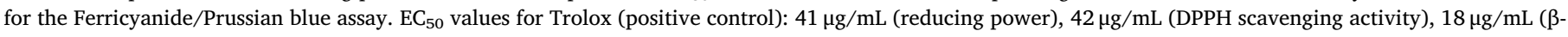
carotene bleaching inhibition) and $23 \mu \mathrm{g} / \mathrm{mL}$ (TBARS inhibition). $\mathrm{GI}_{50}$ values for Ellipticine (positive control): $3.2 \pm 0.7 \mu \mathrm{g} / \mathrm{mL}$.

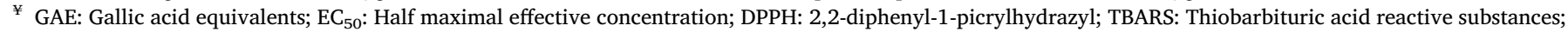
PLP2: non-tumor porcine liver cell line; $\mathrm{GI}_{50}$ : corresponds to the sample concentration achieving $50 \%$ in liver primary culture PLP2.

properties of various cardoon seeds may also present a great diversity depending on the implemented assay, which was also the case in our study. According to Kollia et al. (2016), who applied different extraction techniques (ultrasound assisted and classic extraction) for the evaluation of antioxidant properties of cardoon and artichoke plant parts, the implement extraction protocol may also affect the efficiency of bioactive compounds retrieval and consequently the recorded antioxidant activity. Similar results have been reported by Qadir et al. (2017) where herb extracts from different extraction solvents (methanol, ethanol, acetone, and water) exhibited great differences in antioxidant properties determined via reducing power, and radical scavenging activity assays (DPPH and lipid peroxidation inhibition via linoleic acid). Chen et al. (2013) who correlated total phenolic and flavonoid contents of 43 garlic genotypes with five antioxidant activity assays suggested that the selection of the proper assay is essential for obtaining consistent and reliable results regarding antioxidant properties of natural matrices. Moreover, the higher antioxidant properties of seedcakes obtained from heat extraction comparing to those obtained from cold extraction could be attributed to the thermal inactivation of polyphenol oxidase enzyme (PPO) which is responsible for phenols oxidization (Llorach et al., 2002). Considering that a great portion of total phenols remains in seedcakes after mechanical pressing of seeds (both cold and heat pressing) may further explain the differences in antioxidant properties of seed oils and seedcakes due to different bioactive compounds. It seems that in seed oils antioxidant properties are associated with compounds that are susceptible to thermal oxidation, hence the better antioxidant potential of cold extracted oils. On the other hand, seedcakes contain greater amounts of total phenols, therefore increased temperatures during heat extraction method deactivate phenols oxidizing enzymes and contribute to better antioxidant 
properties. According to the study of Xu et al. (2007) reasonable heating during processing may increase the free fraction of phenolic acids and enhance antioxidant properties of citrus peels, whereas flavonoid glycosides are destroyed by heat treatment. Considering that according to Petropoulos et al. (2018), the main detected phenolic compounds in cardoon seeds were 5-O-caffeoylquinic acid and 3,5-Odicaffeoylquinic acid, this could further explain the positive effect of heat extraction on seedcakes of total phenols and antioxidant properties.

The results of the present study also indicate that growing year is essential for bioactive properties of extracted oils, while extraction method may affect antioxidant potential of oils. The fact that cardoon seeds are rich in oils, allows the implementation of mechanical pressing instead of solvents for oil extraction, being an environmental friendly non-chemical method in an industrial scale (Yang et al., 2013). However, the use of mechanical pressing has the disadvantage of producing great amounts of byproducts (seedcakes) that need to be managed properly in order to alleviate the environmental burden. Therefore, the fact that seedcakes retain the largest portion of phenolic compounds after oil extraction, needs to be further valorized for phenolic compounds isolation, especially when heat mechanical pressing is implemented since this extraction method seems to be more beneficial in terms of bioactive compounds content and antioxidant properties.

All the studied materials show no significant toxicity against nontumor cell line PLP2 up to a $400 \mu \mathrm{g} / \mathrm{mL}$ (Tables 4 and 5). Although most of the studies refer to pharmacological properties of cardoon leaves, the results of the present study are promising regarding the use of cardoon byproducts (seed oils and seedcakes) as alternative sources of bioactive compounds and/or their use in the pharmaceutical industry, since no cytotoxicity were observed. On the contrary, considering the hepatoprotective effects of artichoke and cardoon leaves (Christaki et al., 2012; de Falco et al., 2015), similar properties could be suggested for seed oils and oils byproducts. Seedcakes have been also suggested as potential animal fodder or fertilizer by Curt et al. (2002) due to its high nitrogen content. Therefore, the findings of this study can also support the potential use of seedcakes for animal feedings, since no cytotoxic symptoms were observed.

\section{Conclusion}

Cardoon is a perennial species that has been highly suggested as a multi-purpose crop in the Mediterranean basin during the last three decades. Although biomass production for energy purposes (e.g. solid, gas and liquid biofuel) is the primary industrial use, the high amounts of produced byproducts require their efficient management in order to alleviate the environmental burden, while at the same time the added value of the crop will be also increased. Cardoon seed oils are a rich source of fatty acids, especially linoleic and oleic acid, while seedcakes which are considered as byproducts have the same composition and present better antioxidant properties and higher total phenols than oils. Therefore, finding alternative uses for seedcakes is of major importance in order to increase cardoon's added value, especially as alternative sources of bioactive compounds and fatty acids, as well as organic fertilizers and animal fodder.

The results of the present study show the importance of cardoon as an alternative field crop under the Mediterranean climate conditions. In addition, seed oil production byproducts (e.g. seedcakes) are a promising material due to its bioactivities and its fat content and fatty acid composition that could find alternative uses in the pharmaceutical, the food and the cosmetics industry.

\section{Acknowledgements}

The authors are grateful to theFoundation for Science and Technology (FCT, Portugal) and FEDER under Programme PT2020 for financial support to CIMO (UID/AGR/00690/2013), A. Fernandes grant
(SFRH/BPD/114753/2016), L. Barros and R.C. Calhelha contracts. The authors are also thankful to Emeritus Prof. Gemtos T., Prof. Tsiropoulos N., Dr. Arabatzis D., Dr. Cavalaris C., and Mr. Karamoutis C. for providing the equipment and technical assistance for heat extraction of seed oils. We are also thankful to Mr. Tsagkadopoulos A. and Romfeas N.G.P. (Amygdalea S.A.; Volos, Greece) for providing the equipment and technical assistance for cold extraction of seed oils.

\section{References}

Almeida, C.M., Simões, I., 2018. Cardoon-based rennets for cheese production. Appl. Microbiol. Biotechnol. 4675-4686. https://doi.org/10.1007/s00253-018-9032-3.

Angelini, L.G., Ceccarini, L., Di Nasso, N.N.o, Bonari, E., 2009. Long-term evaluation of biomass production and quality of two cardoon (Cynara cardunculus L.) cultivars for energy use. Biomass Bioenergy 33, 810-816. https://doi.org/10.1016/j.biombioe. 2008.12.004.

Archontoulis, S.V., Struik, P.C., Vos, J., Danalatos, N.G., 2013. Phenological growth stages of Cynara cardunculus: codification and description according to the BBCH scale. Ann. Appl. B 156, 253-270. https://doi.org/10.1111/j.1744-7348.2009. 00384.x.

Azadmard-Damirchi, S., Habibi-Nodeh, F., Hesari, J., Nemati, M., Achachlouei, B.F., 2010. Effect of pretreatment with microwaves on oxidative stability and nutraceuticals content of oil from rapeseed. Food Chem. 121, 1211-1215. https://doi. org/10.1016/j.foodchem.2010.02.006.

Bochkarev, M.S., Egorova, E.Y., Reznichenko, I.Y., Poznyakovskiy, V.M., 2016. Reasons for the ways of using oilcakes in food industry. Foods Raw Mater. 4, 4-12. https:// doi.org/10.21179/2308-4057-2016-1-4-12.

Chen, S., Shen, X., Cheng, S., Li, P., Du, J., Chang, Y., Meng, H., 2013. Evaluation of garlic cultivars for polyphenolic content and antioxidant properties. PLoS One 8. https:// doi.org/10.1371/journal.pone.0079730.

Christaki, E., Bonos, E., Florou-Paneri, P., 2012. Nutritional and functional properties of cynara crops (globe artichoke and cardoon) and their potential applications: a review. Int. J. Appl. Sci. Technol. 2, 64-70.

Curt, M.D., Sánchez, G., Fernández, J., 2002. The potential of Cynara cardunculus L. for seed oil production in a perennial cultivation system. Biomass Bioenergy 23, 33-46. https://doi.org/10.1016/S0961-9534(02)00030-2.

de Falco, B., Incerti, G., Amato, M., Lanzotti, V., 2015. Artichoke: botanical, agronomical, phytochemical, and pharmacological overview. Phytochem. Rev. 14, 993-1018. https://doi.org/10.1007/s11101-015-9428-y.

Delfan-Hosseini, S., Nayebzadeh, K., Mirmoghtadaie, L., Kavosi, M., Hosseini, S.M., 2017. Effect of extraction process on composition, oxidative stability and rheological properties of purslane seed oil. Food Chem. 222, 61-66. https://doi.org/10.1016/j. foodchem.2016.11.150.

Durazzo, A., Foddai, M., Temperini, A., Azzini, E., Venneria, E., Lucarini, M., Finotti, E., Maiani, G., Crinò, P., Saccardo, F., Maiani, G., 2013. Antioxidant properties of seeds from lines of artichoke, cultivated cardoon and wild cardoon. Antioxidants 2, 52-61. https://doi.org/10.3390/antiox2020052.

Fernández, J., Curt, M.D., Aguado, P.L., 2006. Industrial applications of Cynara cardunculus L. for energy and other uses. Ind. Crops Prod. 24, 222-229. https://doi.org/10. 1016/j.indcrop.2006.06.010.

Ferreira-Dias, S., Gominho, J., Baptista, I., Pereira, H., 2018. Pattern recognition of cardoon oil from different large-scale field trials. Ind. Crops Prod. 118, 236-245. https:// doi.org/10.1016/j.indcrop.2018.03.038.

Foti, S., Mauromicale, G., Raccuia, S.A., Fallico, B., Fanella, F., Maccarone, E., 1999. Possible alternative utilization of Cynara spp. I. Biomass, grain yield and chemical composition of grain. Ind. Crops Prod. 10, 219-228. https://doi.org/10.1016/S09266690(99)00026-6.

Genovese, C., Platania, C., Venticinque, M., Calderaro, P., Argento, S., Scandurra, S., Raccuia, S.A., 2016. Evaluation of cardoon seeds presscake for animal feeding. Acta Hortic. 1147, 223-228. https://doi.org/10.17660/ActaHortic.2016.1147.45.

Gominho, J., Lourenço, A., Palma, P., Lourenço, M.E., Curt, M.D., Fernández, J., Pereira, H., 2011. Large scale cultivation of Cynara cardunculus L. for biomass production-a case study. Ind. Crops Prod. 33, 1-6. https://doi.org/10.1016/j.indcrop.2010.09. 011.

Grammelis, P., Malliopoulou, A., Basinas, P., Nicholas, G., 2008. Cultivation and characterization of Cynara cardunculus for solid biofuels production in the Mediterranean region. Int. J. Mol. Sci. 9, 1241-1258. https://doi.org/10.3390/ijms9071241.

Guil, J.L., Torija, M.E., Giménez, J.J., Rodriguez, I., 1996. Identification of fatty acids in edible wild plants by gas chromatography. J. Chromatogr. A 719, 229-235. https:// doi.org/10.1007/s12161-008-9063-y.

Heleno, S.A., Barros, L., Sousa, M.J., Martins, A., Ferreira, I.C.F.R., 2009. Study and characterization of selected nutrients in wild mushrooms from Portugal by gas chromatography and high performance liquid chromatography. Microchem. J. 93, 195-199. https://doi.org/10.1016/j.microc.2009.07.002.

Kollia, E., Markaki, P., Zoumpoulakis, P., Proestos, C., 2016. Antioxidant activity of Cynara scolymus L. and Cynara cardunculus L. extracts obtained by different extraction techniques. Nat. Prod. Res. 31, 1163-1167. https://doi.org/10.1080/14786419. 2016.1219864.

Kozłowska, M., Gruczyńska, E., Ścibisz, I., Rudzińska, M., 2016. Fatty acids and sterols composition, and antioxidant activity of oils extracted from plant seeds. Food Chem. 213, 450-456. https://doi.org/10.1016/j.foodchem.2016.06.102.

Liu, L., Hu, Q., Wu, H., Xue, Y., Cai, L., Fang, M., Liu, Z., Yao, P., Wu, Y., Gong, Z., 2016. Protective role of $n 6 / n 3$ PUFA supplementation with varying DHA/EPA ratios against 
atherosclerosis in mice. J. Nutr. Biochem. 32, 171-180. https://doi.org/10.1016/j. jnutbio.2016.02.010.

Llorach, R., Espín, J.C., Tomás-Barberán, F.A., Ferreres, F., 2002. Artichoke (Cynara scolymus L.) byproducts as a potential source of health-promoting antioxidant phenolics. J. Agric. Food Chem. 50, 3458-3464. https://doi.org/10.1021/jf0200570.

Maccarone, E., Fallico, B., Fanella, F., Mauromicale, G., Raccuia, S.A., 1999. Possible alternative utilization of Cynara spp. II. Chemical characterization of their grain oil. Ind. Crops Prod. 10, 229-237. https://doi.org/10.1016/S0926-6690(99)00027-8.

Pagnotta, M.A., Fernandez, J.A., Sonnante, G., Egea-Gilabert, C., 2017. Genetic diversity and accession structure in European Cynara cardunculus collections. PLoS One 12, 1-23. https://doi.org/10.1371/journal.pone.0178770.

Petropoulos, S.A., Pereira, C., Barros, L., Ferreira, I.C.F.R., 2017. Leaf parts from Greek artichoke genotypes as a good source of bioactive compounds and antioxidants. Food Funct. 8, 2022-2029. https://doi.org/10.1039/c7fo00356k.

Petropoulos, S.A., Pereira, C., Tzortzakis, N., Barros, L., Ferreira, I.C.F.R., 2018. Nutritional value and bioactive compounds characterization of plant parts from Cynara cardunculus L. (Asteraceae) cultivated in central Greece. Front. Plant Sci. 9. https://doi.org/10.3389/fpls.2018.00459.

Qadir, M.A., Shahzadi, S.K., Bashir, A., Munir, A., Shahzad, S., 2017. Evaluation of phenolic compounds and antioxidant and antimicrobial activities of some common herbs. Int. J. Anal. Chem. 2017https://doi.org/10.1155/2017/3475738. Article ID 3475738, 6 pages.

Raccuia, S.A., Piscioneri, I., Sharma, N., Melilli, M.G., 2011. Genetic variability in Cynara cardunculus $\mathrm{L}$. domestic and wild types for grain oil production and fatty acids composition. Biomass Bioenergy 35, 3167-3173. https://doi.org/10.1016/j. biombioe.2011.04.047.

Renna, M., Signore, A., Paradiso, V.M., Santamaria, P., 2018. Faba greens, globe artichoke's offshoots, crenate broomrape and summer squash greens: unconventional vegetables of Puglia (Southern Italy) with good quality traits. Front. Plant Sci. 9, 1-13. https://doi.org/10.3389/fpls.2018.00378.

Sarmento, A., Barros, A., Fernandes, Â., Carvalho, A., Ferreira, I., 2015. Valorization of traditional foods: nutritional and bioactive properties of Cicer arietinum L. and Lathyrus sativus L. pulses. J. Sci. Food Agric. 95, 179-185. https://doi.org/10.1002/ jsfa.6702.

Siger, A., Dwiecki, K., Borzyszkowski, W., Turski, M., Rudzińska, M., Nogala-Kałucka, M., 2017. Physicochemical characteristics of the cold-pressed oil obtained from seeds of Fagus sylvatica L. Food Chem. 225, 239-245. https://doi.org/10.1016/j.foodchem. 2017.01.022.

Simopoulos, A.P., 1999. Essential fatty acids in health and chronic disease. Am. J. Clin. Nutr. 70, 560-569. https://doi.org/10.1093/ajcn/70.3.560s.

Sobral, F., Sampaio, A., Falcão, S., Queiroz, M., Calhelha, R., Vilas-Boas, M., Ferreira, I., 2016. Chemical characterization, antioxidant, anti-inflammatory and cytotoxic properties of bee venom collected in Northeast Portugal. Food Chem. Toxicol. 94, 172-177. https://doi.org/10.1016/j.fct.2016.06.008.

Vasilakoglou, I., Dhima, K., 2014. Potential of two cardoon varieties to produce biomass and oil under reduced irrigation and weed control inputs. Biomass Bioenergy 63, 177-186. https://doi.org/10.1016/j.biombioe.2014.01.052.

Venter, M.J., Willems, P., Kuipers, N.J.M., Haan, A.B., de, 2006. Gas assisted mechanical expression of cocoa butter from cocoa nibs and edible oils from oilseeds. J. Supercrit. Fluids 37, 350-358. https://doi.org/10.1016/j.supflu.2005.12.015.

Willems, P., Kuipers, N.J.M., De Haan, A.B., 2008. Hydraulic pressing of oilseeds: experimental determination and modeling of yield and pressing rates. J. Food Eng. 89, 8-16. https://doi.org/10.1016/j.jfoodeng.2008.03.023.

Wolfe, K., Xianzhong, W., Liu, R.H., 2003. Antioxidant activity of apple peels. J. Agric. Food Chem. 51, 609-614. https://doi.org/10.1021/jf020782a.

Xu, G., Ye, X., Chen, J., Liu, D., 2007. Effect of heat treatment on the phenolic compounds and antioxidant capacity of citrus peel extract. J. Agric. Food Chem. 55, 330-335. https://doi.org/10.1021/jf0625171.

Yang, M., Huang, F., Liu, C., Zheng, C., Zhou, Q., Wang, H., 2013. Influence of microwave treatment of rapeseed on minor components content and oxidative stability of oil. Food Bioprocess Technol. 6, 3206-3213. https://doi.org/10.1007/s11947-0120987-2.

Zanetti, F., Monti, A., Berti, M.T., 2013. Challenges and opportunities for new industrial oilseed crops in EU-27: a review. Ind. Crops Prod. 50, 580-595. https://doi.org/10. 1016/j.indcrop.2013.08.030. 